\title{
Bacterial Leaf Spot of Lettuce: Relationship of Temperature to Infection and Potential Host Range of Xanthomonas campestris pv. vitians
}

\author{
P. E. Robinson, Graduate Research Assistant, and J. B. Jones, Professor, Department of Plant Pathology, University \\ of Florida, Institute of Food and Agricultural Sciences (IFAS), Gainesville 32611; and Ken Pernezny, Professor, \\ Department of Plant Pathology, IFAS, University of Florida, Everglades Research and Education Center, Belle Glade \\ 33430
}

\begin{abstract}
Robinson, P. E., Jones, J. B., and Pernezny, K. 2006. Bacterial leaf spot of lettuce: Relationship of temperature to infection and potential host range of Xanthomonas campestris pv. vitians. Plant Dis. 90:465-470.

Epidemiological aspects, including optimum temperature for infection and host range of Xanthomonas campestris pv. vitians, causal organism of bacterial leaf spot (BLS) of lettuce, were investigated. The optimum temperature for infection was determined to be $22.7^{\circ} \mathrm{C}$ based on growth chamber studies. Internal populations were monitored over time in lettuce, tomato, pepper, parsley, cilantro, and beet. Each plant species was infiltrated with the bacterium at $10^{5}$ $\mathrm{CFU} / \mathrm{ml}$. Highest populations developed in lettuce $\left(10^{8} \mathrm{CFU} / \mathrm{cm}^{2}\right)$ followed by pepper with $10^{6}$ $\mathrm{CFU} / \mathrm{cm}^{2}$, whereas the other plant species harbored much lower populations $\left(10^{5}\right.$ to $10^{3}$ $\left.\mathrm{CFU} / \mathrm{cm}^{2}\right)$. Infectivity titration endpoints were similar in pepper and lettuce $\left(10^{3}\right.$ to $\left.10^{4} \mathrm{CFU} / \mathrm{ml}\right)$. For other plant species tested, infectivity titration endpoints were $10^{6}$ to $10^{7} \mathrm{CFU} / \mathrm{ml}$. Electrolyte leakage data and corresponding internal population data support the conclusion that fresh-market tomato is not a host of $X$. campestris pv. vitians but, instead, interacts in an incompatible response. Electrolyte leakage from cells of tomato plants inoculated with X. campestris pv. vitians or a pepper strain of $X$. axonopodis pv. vesicatoria peaked at $48 \mathrm{~h}$, suggesting that tomato is not a host for the BLS pathogen. Both electrolyte leakage and population dynamics results point to pepper as a potential host of $X$. campestris pv. vitians.
\end{abstract}

Additional keywords: Lactuca sativa

The first reported epidemic of bacterial leaf spot (BLS) of lettuce (Lactuca sativa L.), caused by Xanthomonas campestris pv. vitians, in Florida, occurred in the winter vegetable season (November to March) of 1992-93 (23). The disease caused approximately $\$ 4$ million in losses. BLS has been reported in other areas of the world, with many outbreaks occurring within a few years of the Florida epidemic $(3,8,21$, $22,24,26,27,30,33)$. Substantial economic losses were reported in California (5), Ohio (27), and Quebec, Canada (30). Contaminated seed have been suggested as a possible source of these temporally associated outbreaks in various lettuce-growing areas around the globe $(5,27,33)$. So far, only lettuce has been reported to be a natural host of this bacterium in the field.

Symptoms of BLS initially consist of water-soaked leaf lesions that rapidly be-

Corresponding author: K. Pernezny

E-mail: klp@ifas.ufl.edu

This research was supported by the Florida Agricultural Experiment Station, and approved for publication as Journal Series No. R-10826.

Accepted for publication 2 November 2005.

DOI: 10.1094/PD-90-0465

(C) 2006 The American Phytopathological Society come black, followed by tissue collapse. Later, lesions become dry and papery in appearance. BLS generally does not reduce plant size, but renders lettuce unmarketable due to the unsightly leaf blemishes. Several groups have found that cos (romaine) and butterhead lettuce are most susceptible to BLS $(5,23,30)$.

Optimum temperatures reported for BLS infection vary. Brown (4) first described the causal organism and found the optimum temperature for in vitro growth of the bacterium to be between 26 and $28^{\circ} \mathrm{C}$. The outbreak which prompted Brown's study occurred after a sudden cold spell in February in South Carolina. However, Patterson et al. (21) considered BLS as occurring in relatively warm weather. Toussaint (30) also found the optimal temperature for in vitro growth of $X$. campestris pv. vitians to be approximately $28^{\circ} \mathrm{C}$ and observed an epidemic under conditions considered warm for Canada; on some days high temperatures were near $30^{\circ} \mathrm{C}(1,32)$. The 1992-93 vegetable season in Florida was considered rather warm and rainy (2). In Italy, an epidemic of BLS occurred after an unusual cold spell in November, with accumulated frost (22). It is obvious from these conflicting reports that specific, controlled studies are needed to clearly establish the temperatures that are optimal for BLS infection.
The scope of the vegetable industry in the Everglades Agricultural Area (EAA) of southern Florida has changed significantly over the past 12 years. Concentrated, large acreages of crops, such as celery (Apium graveolens L.) and lettuce, have been replaced to a significant degree by generally smaller plantings of assorted salad crops. These alternative crops include endive (Cichorium endivia L.), escarole ( $C$. endivia L.), radicchio (C. intybus L.), spinach (Spinacia oleracae L.), and several herbs (e.g., parsley [Petroselinum crispum (Mill.) Nym. ex. A.W. Hill] and cilantro [Coriandrum sativum L.]). Most producers grow these diverse "spring mix" salad crops in close spatial and temporal proximity. Growers are concerned that $X$. campestris pv. vitians may infect these other crops. All crops are watered from below using a seepage irrigation system. However, some winters in Florida see significant rainfall in what is normally the dry season, creating conditions conducive to spread of $X$. campestris pv. vitians. Sahin and Miller (28) already have reported that tomato (Lycopersicon esculentum Mill.) and pepper (Capsicum annuum L.) are hosts of $X$. campestris pv. vitians. Tsuchiya et al. (31) produced an extensive list of host plants with observable symptoms after inoculation with $X$. campestris pv. vitians.

Several methods can be used to more fully elucidate the host range of a pathogen. These include infectivity titration experiments, in vivo population dynamics, and electrolyte leakage studies. Infectivity titration has been used to judge the relative susceptibility of genotypes to challenge from a potential pathogen (11). In typical infectivity titration experiments, a range of inoculum concentrations (e.g., $10^{8}, 10^{7}$, $\left.10^{6} \ldots 10^{1} \mathrm{CFU} / \mathrm{ml}\right)$ is applied to test plants. The end point often established is the lowest concentration that results in detectable disease symptoms (11). In vivo population dynamics refers to measurements of internal populations of the pathogen in leaf tissue of intact plants at several times after infiltration of inoculum. Electrolyte leakage is a method used to study the egress of ions from cells $(18,19)$. Cook and Stall (7) established correlations between host susceptibility and electrical conductance, reporting that the susceptible reaction in pepper involves a relatively slow and gradual increase in conductance of a solution 
surrounding infiltrated cells. Conductance values increase more rapidly when a resistant plant is infiltrated.

The objectives of this study were to (i) determine the optimum temperature for development of BLS on cos lettuce and (ii) clarify the host range of $X$. campestris pv. vitians using infectivity titration, in vivo population dynamics, and electrolyte leakage measurements.

\section{MATERIALS AND METHODS}

Growth of plants. Seed of all crop species studied were planted in a commercial potting mix (Farfard Soil Mix No.2; Conrad Farfard, Inc., Agawan, MA) in 10-cm plastic pots. After emergence, each pot received $2.6 \mathrm{~g}$ of a slow-release fertilizer (Osmocote 15-9-12; Sierra Chemical Co., Milpitas, CA). Additional units of fertilizer were added as needed based on the appearance of the individual crop. Greenhouse experiments were carried out in an air-conditioned unit with maximum temperatures of 26 to $28^{\circ} \mathrm{C}$.

Inoculum preparation and inoculation. X. campestris pv. vitians, strain L7, recovered from a commercial lettuce field in 1993 (23), was used in these studies. Bacteria were grown for $72 \mathrm{~h}$ on nutrient agar amended with $0.5 \%$ (aqueous wt/vol) glucose (GNA). Plates were flooded with sterile, phosphate-buffered saline (PBS; 17), and resultant suspensions were adjusted turbidimetrically to approximately 1 $\times 10^{8} \mathrm{CFU} / \mathrm{ml}$ before dilution. Stock cultures were maintained in $15 \%$ aqueous glycerol at $-70^{\circ} \mathrm{C}$. Applications of bacterial suspensions to all plant species in all experiments were made by misting both the adaxial and abaxial plant surfaces to runoff using a handheld sprayer. All inoculations were done between 0900 and $1200 \mathrm{~h}$. Two drops of Tween 80 were added to 200 $\mathrm{ml}$ of inoculum suspension to enhance wetting of leaf surfaces.

Optimum temperature for infection. The optimum temperature for infection was investigated in a series of growth chamber studies. Twenty 4-to 6-week-old cos lettuce plants (approximately 18 leaves in whorls), cv. Valmaine, grown in individual pots, were spray inoculated with a $10^{8}$ $\mathrm{CFU} / \mathrm{ml}$ suspension as described above. All plants then were enclosed in clear plastic bags. Five pots each were placed in each of four growth chambers (Controlled Environments Inc., Pembina, ND) at 15, 20, 25, and $30^{\circ} \mathrm{C}$. Fluorescent light was provided at $195 \mu$ moles $\mathrm{m}^{-2} \mathrm{sec}^{-1}$ on a $12-\mathrm{h}$ photoperiod. Two control plants were sprayed with sterile PBS, bagged, and placed in each growth chamber. After 3 days, bags were removed. Disease ratings were made approximately 10 days later. Disease was assessed by counting all BLS lesions on each plant. Isolations were made from representative lesions to confirm that they were caused by $X$. campestris pv. vitians. The number of lesions was regressed on temperature using the GLM procedure of the Statistical Analysis System (SAS Institute, Cary, NC). Slope and $y$-intercept values were used to write a regression equation for the relationship between temperature and disease rating. The optimum temperature then was estimated by setting the first derivative of the equation to zero (i.e., slope $=0$ ), and solving for $x$ (temperature) (9). The experiment was repeated three times with similar results.

In vivo population dynamics. Suspensions of $X$. campestris pv. vitians, strain L7R, were used in these greenhouse studies. L7R was selected as a one-step spontaneous mutant of $\mathrm{L} 7$ recovered by plating $200 \mu \mathrm{l}$ of a turbid suspension of L7 on GNA containing rifampicin at $100 \mu \mathrm{g} / \mathrm{ml}$. The following crops were used: cilantro, cv. Slobolt; parsley, cv. Forest Green; beet, cv. Darko; tomato, cv. Sunny; pepper, cv. Jupiter; and lettuce, cv. Valmaine. Young leaves on three replicate plants were injected with approximately $0.03 \mathrm{ml}$ of the suspension using a hypodermic syringe fitted with a 27 -gauge needle, and plants were set on the greenhouse bench at the condition listed above. One leaf from each of the three test plants was removed for in vivo population determinations on each sampling date. Controls consisted of two plants of each crop infiltrated with sterile water. Inoculated leaves were collected at various times after inoculation and surface sterilized by dipping in a $0.525 \%$ sodium hypochlorite solution followed by a rinse in deionized water. Leaves were blotted until dry with sterile paper towels. A $1-\mathrm{cm}^{2}$ area of leaf tissue centered at inoculation sites was cut out and ground in $2 \mathrm{ml}$ of PBS, serially diluted, and plated on GNA amended with rifampicin at $100 \mu \mathrm{g} / \mathrm{ml}$. Populations were determined $0,1,3,5,8$, 11 , and 14 days after inoculation (DAI) and expressed as $\mathrm{CFU} / \mathrm{cm}^{2}$ of fresh tissue. Population trends were recorded over time. These experiments were done twice.

Infectivity titrations. A series of spray inoculations with $X$. campestris pv. vitians at $10^{7}$ to $10^{8} \mathrm{CFU} / \mathrm{ml}$ were carried out for a wide range of crop species. These included arugula (Eruca vesicaria var. sativa Mill), beet (Beta vulgaris L.), cabbage (Brassica oleracea var. capitata L.), carrot (Daucus carota L.), celery, chicory (Cichorium endivia L.), dandelion (Taraxacum officinale Weber), dill (Anethum graveolens L.), mizuna mustard (Brassica rapa L. var. japonica), radicchio, spinach, Swiss chard (Beta vulgaris L.), tatsoi (Brassica rapa L.), or upland cress (Barbarea verna Mill.).

Based on the results of these initial spray inoculations, infectivity titration experiments were conducted using the cultivars listed above for cilantro, parsley, tomato, pepper, and lettuce with the addition of endive, cv. Markant. A suspension of strain L7 initially was prepared at $10^{8}$
$\mathrm{CFU} / \mathrm{ml}$ and diluted in 10-fold increments to produce six additional suspensions from $10^{7}$ to $10^{2} \mathrm{CFU} / \mathrm{ml}$. Each suspension then was used to spray inoculate three replicate plants of each test species. Plants were kept in the greenhouse at the conditions listed above. Plants were enclosed in clear plastic bags for 3 days after inoculation and examined for appearance of symptoms 10 to 11 days later. Due to limitations of greenhouse space, three or four crop species were tested at a time. In all tests, lettuce was used to compare infectivity titration endpoints with the other crops. Each crop was evaluated in at least two experiments.

Electrolyte leakage. The hypersensitive reaction was evaluated in tomato and pepper by measurement of electrolyte leakage over time in leaflets infiltrated with high concentrations $\left(10^{8} \mathrm{CFU} / \mathrm{ml}\right)$ of a bacterial suspension. Also, in these experiments, additional in vivo population determinations were made in leaf tissue infiltrated with low bacterial populations $\left(10^{5}\right.$ $\mathrm{CFU} / \mathrm{ml})$. These experiments were conducted in growth chambers at $28^{\circ} \mathrm{C}$.

Electrolyte leakage was determined in tomato cv. Bonny Best and pepper cv. Early Cal Wonder by infiltrating a $10^{8}$ $\mathrm{CFU} / \mathrm{ml}$ suspension of $X$. campestris pv. vitians (L7); X. axonopodis pv. vesicatoria pepper race, strain $\mathrm{P} 1$; and $X$. axonopodis pv. vesicatoria tomato race, strain 91118 into approximately $5 \mathrm{~cm}^{2}$ of leaf area. P1 is a strain which infects pepper only and 91118 is a T3 strain that infects tomato only. Electrical conductivity of water in baths containing submerged, inoculated tissues was determined as previously described (15) with samples taken at 12-h intervals after infiltration. Each treatment was replicated three times and the experiment was repeated once.

In the bacterial population studies, approximately $1 \mathrm{~cm}^{2}$ of leaf tissue from tomato and pepper was infiltrated with bacterial suspensions containing the above strains of $X$. campestris pv. vitians (L7), $X$. axonopodis pv. vesicatoria (pepper race), and $X$. axonopodis pv. vesicatoria (tomato race) at $10^{5} \mathrm{CFU} / \mathrm{ml}$. Populations in tomato were determined for each strain from three leaflets every 2 days for 10 days. Sections of leaf tissue $\left(1 \mathrm{~cm}^{2}\right)$ at inoculation sites were removed and triturated in sterile PBS. The subsequent suspensions were serially diluted in sterile PBS and 100- $\mu \mathrm{l}$ aliquots were spread on plates of GNA. Plates were incubated at $28^{\circ} \mathrm{C}$ for 72 $\mathrm{h}$, and colonies enumerated. Populations were expressed as $\mathrm{CFU} / \mathrm{cm}^{2}$. Populations in pepper were determined for each strain in three leaves every 2 days for 14 days.

\section{RESULTS}

A curvilinear relationship was observed between temperature and infectivity on cos lettuce (Fig. 1). Lesion numbers per leaf were very low at $15^{\circ} \mathrm{C}$ and were noticeably 
reduced again at $30^{\circ} \mathrm{C}$. The regression equation for the relationship was $y=$ $-5695.3+588.2 x-12.9 x^{2}\left(R^{2}=0.33, P<\right.$ 0.03 ), where $x=$ temperature and $y=$ average number of lesions per leaf. On differentiation of the equation and setting of $d y / d x$ to zero, the optimum temperature for infection was estimated as $22.7^{\circ} \mathrm{C}$.

In vivo populations of $X$. campestris $\mathrm{pv}$. vitians developed to their highest levels as expected in lettuce, peaking at $3.5 \times 10^{8}$ $\mathrm{CFU} / \mathrm{cm}^{2} 8 \mathrm{DAI}$ and $1.1 \times 10^{8} \mathrm{CFU} / \mathrm{cm}^{2} 5$ DAI in two separate trials (Fig. 2). The next highest populations observed were in pepper leaves, reaching $5.8 \times 10^{6} \mathrm{CFU} / \mathrm{cm}^{2}$ $10 \mathrm{DAI}$ and $5.5 \times 10^{6} \mathrm{CFU} / \mathrm{cm}^{2} 5 \mathrm{DAI}$ in two experiments. Populations in other crops generally were much lower $\left(10^{3}\right.$ to $10^{4} \mathrm{CFU} / \mathrm{cm}^{2}$ ).

No disease reactions ever were observed for arugula, beet, cabbage, carrot, celery, chicory, dandelion, dill, mizuna mustard, radicchio, spinach, Swiss chard, tatsoi, or upland cress. Possible disease reactions, consisting of water-soaked lesions that later become necrotic, were observed for cilantro, endive, and, to some extent, parsley.

Based on the above results, infectivity titration experiments were conducted for cilantro, endive, and parsley, as well as tomato and pepper (28). Infectivity titration endpoints for lettuce and pepper were consistently the lowest values observed, $10^{4}$ to $10^{3} \mathrm{CFU} / \mathrm{ml}$ depending on the experiment. Symptoms on pepper were indistinguishable from those of bacterial spot, caused by $X$. axonopodis pv. vesicatoria (16). In contrast, endpoints for cilantro, endive, and parsley were $10^{6}, 10^{6}$, and $10^{7}$ $\mathrm{CFU} / \mathrm{ml}$, respectively. Symptoms on these plants were somewhat like those of typical BLS on lettuce, consisting of water-soaked spots that later became necrotic. No symptoms were observed on tomato plants at any concentration tested.

$X$. axonopodis pv. vesicatoria $(\mathrm{P} 1)$ and $X$. campestris. pv. vitians (L7R) produced a sharp increase (up to 390 and 350 $\mu \mathrm{Mhos}$, respectively) in electrolyte leakage from tomato leaf tissue up to $48 \mathrm{~h}$ after infiltration (Fig. 3A). The increase in electrolyte leakage for the tomato race of $X$. axonopodis pv. vesicatoria was noticeably more gradual, occurring over a 5-day period, eventually peaking at $438 \mu$ Mhos. After an initial rapid increase, internal populations of $X$. campestris pv. vitians and the pepper race of $X$. axonopodis pv. vesicatoria leveled off at $10^{5} \mathrm{CFU} / \mathrm{cm}^{2}$ compared with the tomato race, which reached maximum populations of $10^{9}$ CFU/cm² (Fig. 3B).

In pepper, the highest conductivity readings occurred for the tomato race of $X$. axonopodis pv. vesicatoria (strain 9118), with a value of $257 \mu$ Mhos at $48 \mathrm{~h}$ (Fig. 4). $X$. campestris pv. vitians (L7) reached 190 $\mu$ Mhos at $48 \mathrm{~h}$, followed by a rapid decline. The pepper race (strain P1) reached $198 \mu \mathrm{Mhos}$ at $48 \mathrm{~h}$ and remained near that level for $120 \mathrm{~h}$. Internal populations of the tomato strain were one to two log units lower than the pepper strain and $X$. campestris pv. vitians, which both increased to $10^{9} \mathrm{CFU} / \mathrm{cm}^{2}$ in leaflets.

The electrolyte leakage patterns for X. campestris pv. vitians and the pepper race of $X$. axonopodis pv. vesicatoria in tomato were remarkably similar (Fig. 4A). Maximum conductivity of approximately 190

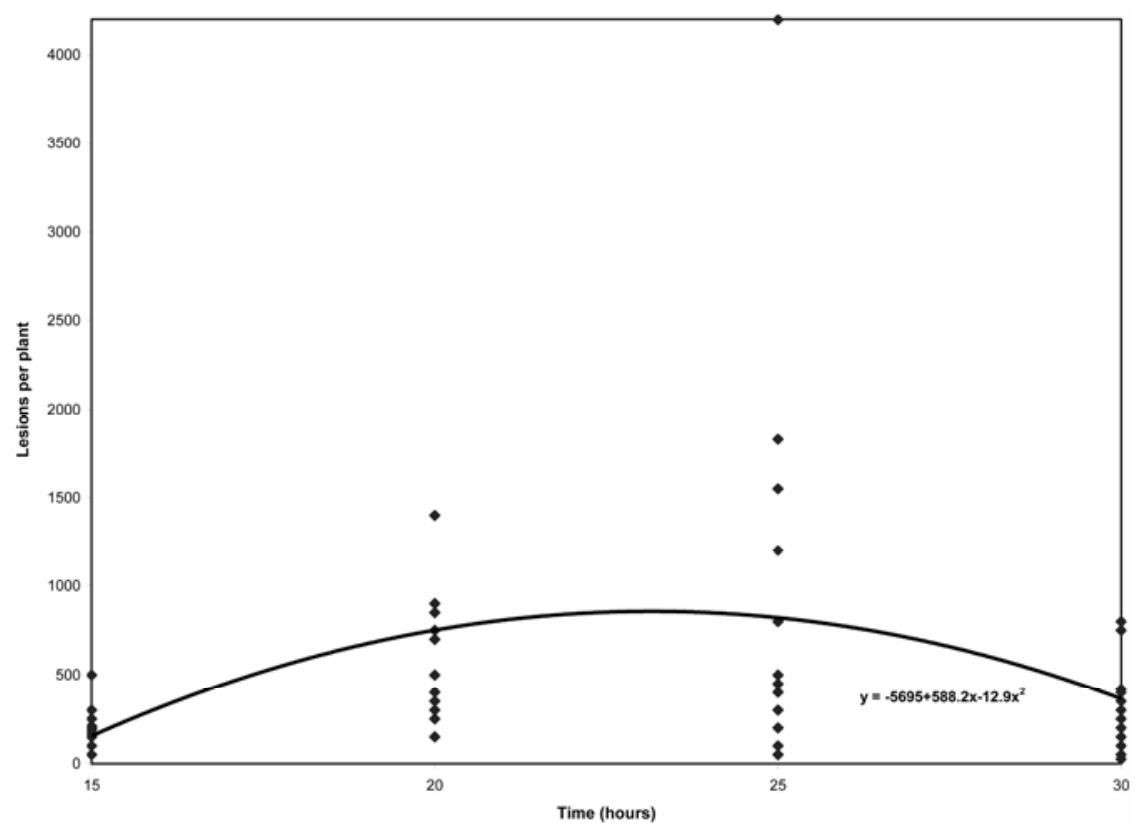

Fig. 1. Effect of temperature on bacterial leaf spot (BLS) development on lettuce plants inoculated with Xanthomonas campestris pv. vitians. Scatterplot of regression $\left(y=-5695.29+588.2 x-12.90 x^{2}\right)$ $\left(R^{2}=0.33, P<0.03\right)$ with combined data from three experiments. Disease severity was estimated by counting all BLS lesions on each test plant 12 days after inoculation. Data points are means of five plants per experiment placed in controlled environment chambers at each of four temperatures: 15,20 , 25 , and $30^{\circ} \mathrm{C}$.

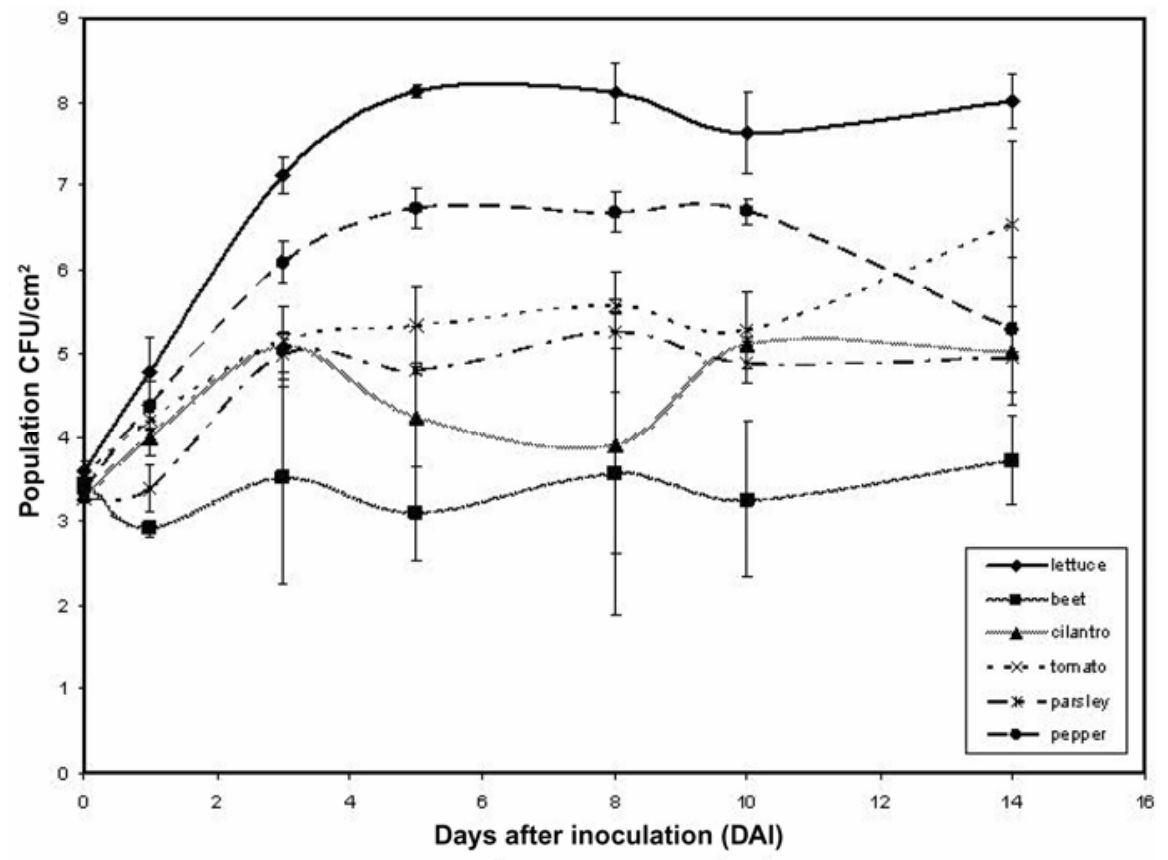

Fig. 2. Bacterial populations in leaf tissues of lettuce, beet, cilantro, parsley, pepper, and tomato over a 2-week period from a representative experiment following infiltration with Xanthomonas campestris pv. vitians strain L7R at $10^{5} \mathrm{CFU} / \mathrm{ml}$.

$\mu$ Mhos was observed for both at $48 \mathrm{~h}$ after infiltration. In contrast, leakage was much with the tomato race of $X$. axonopodis pv. vesicatoria, reaching $260 \mu \mathrm{Mhos}$ at $48 \mathrm{~h}$.

In vivo populations of $X$. campestris pv. vitians and the pepper race of $X$. campespv. axonopodis increased to nearly $10^{10} \mathrm{CFU} / \mathrm{cm}^{2}$ in pepper during the course of these experiments (Fig. 4B). The popu-$$
\text { . }
$$ 
lations of the tomato race of $X$. axonopodis pv. vesicatoria were two to four log units less, depending on the sampling date.

\section{DISCUSSION}

Based on controlled growth chamber studies, it appears that BLS of lettuce is a "cool weather" disease, with an estimated optimum temperature for infection of about $23^{\circ} \mathrm{C}$. When cooler-than-normal winters occur in southern Florida, growers should be on alert for possible occurrence of BLS. It may not be surprising that BLS is favored by cool weather. Lettuce is considered to be a cool-season vegetable, and one might expect $X$. campestris pv. vitians to be adapted to attacking its host under such conditions. The winter of 2002-03 was such a season and, indeed, BLS was widespread and damaging in Florida lettuce fields (R. Raid and K. Pernezny, personal observation; 10). However, 2002-03 also was wetter than normal, and rainfall is critical to the dispersal of BLS bacteria. Thus, it is not possible to conclude from this outbreak that cool temperatures or rainy conditions likely contribute more to BLS outbreaks. There was no reason to suspect that the L7 strain was not typical of those collected from Florida fields during cool, damp seasons associated with BLS epidemics. However, it is possible that strains may differ between locations and within production areas. It would be helpful to collect strains from different locations and to compare temperature optima. Differences in strains could account for differences in
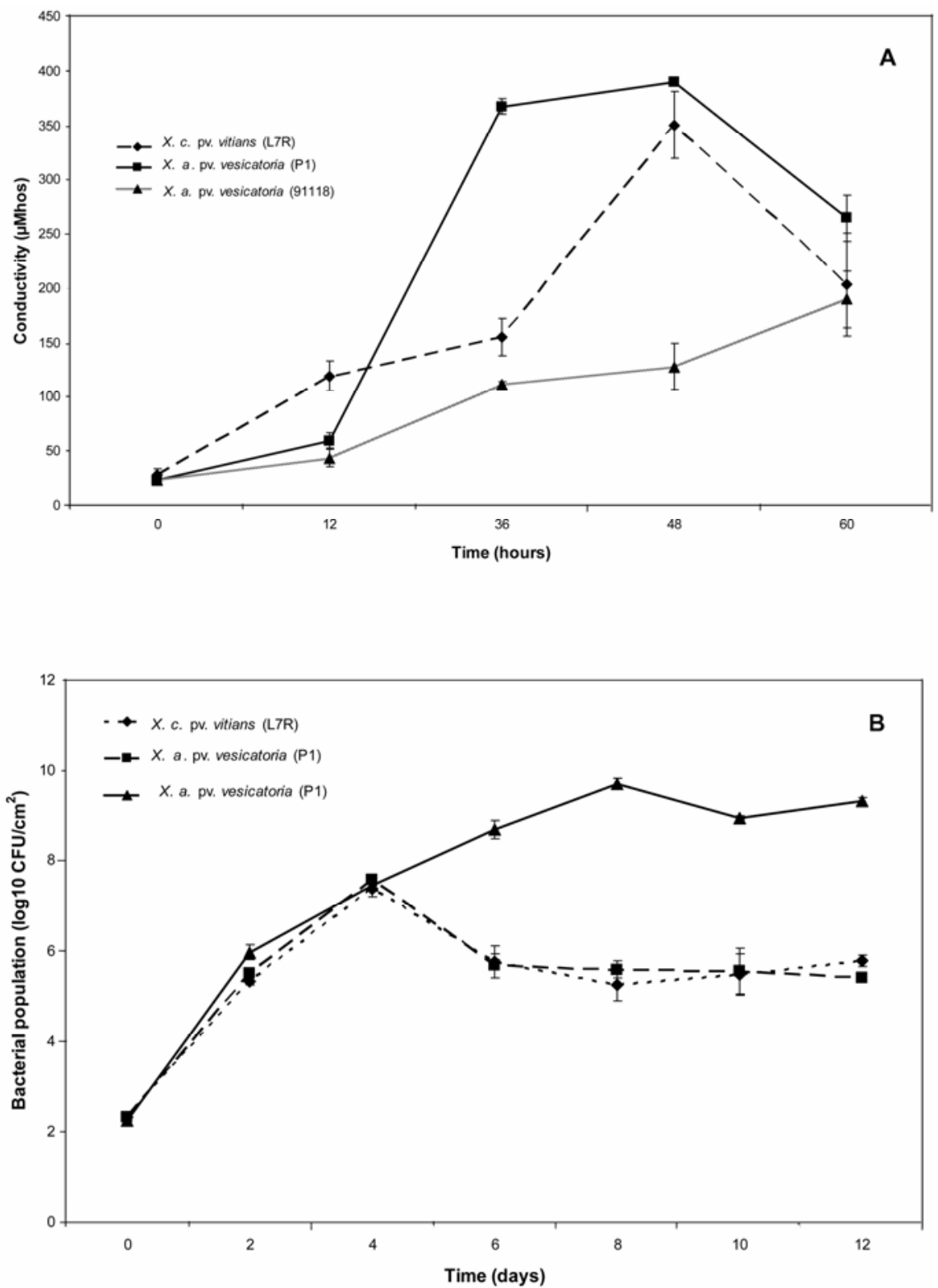

Fig. 3. Effect of infiltrating Xanthomonas campestris pv. vitians, strain L7R; a strain (P1) of the pepper race $X$. axonopodis pv. vesicatoria that infects only pepper; and strain 91118 of the tomato race of Xanthomonas axonopodis pv. vesicatoria, a T3 strain which infects tomato only, at $10^{8} \mathrm{CFU} / \mathrm{ml}$ on A, electrolyte leakage and $\mathbf{B}$, bacterial populations in tomato plants. Means and standard error bars are shown for three replicates of each host-bacterium combination at each sampling time. reports of temperatures optimal for BLS outbreaks.

Internal populations of $X$. campestris pv. vitians were highest in lettuce compared with the other inoculated plant species. Populations developed to maximum levels of about $10^{8} \mathrm{CFU} / \mathrm{cm}^{2}$. Pepper also supported high internal populations, supporting the thesis of Sahin and Miller (28) that pepper is likely an alternative host of $X$. campestris pv. vitians. Populations in tomato, parsley, cilantro, and beet were as much as four log units lower than those of lettuce. Therefore, it is unlikely that these crops become infected and serve as alternate hosts of $X$. campestris pv. vitians. However, it is possible that they could serve as hosts of epiphytic populations of $X$. campestris pv. vitians. The role of epiphytic populations on other crops in the epidemiology of BLS was not determined in these studies.

Infectivity titration is another approach that can be taken to define the potential compatibility of hosts and pathogens. For example, it has been used to help identify cultivars of crops that differ in levels of resistance to a number of bacterial pathogens. Chamberlain (6) was not able to see differences in susceptibility of soybean to $X$. campestris pv. glycines until inoculum concentrations were reduced to $10^{5}$ CFU/ml. Similarly, Foster and Echandi (14) found that high inoculum concentrations obscured resistance in Lycopersicon hirsutum accessions to Clavibacter michiganensis subsp. michiganensis. They suggested screening for resistance to this tomato pathogen at $10^{5} \mathrm{CFU} / \mathrm{ml}$. Use of inoculum concentrations of $10^{7} \mathrm{CFU} / \mathrm{ml}$ or higher may mislead observers studying $X$. campestris pv. vitians and could account for reports of a wide host range for this pathogen (31). In preliminary tests, we inoculated a large number of salad and several herb crops with $10^{7}$ to $10^{8} \mathrm{CFU} / \mathrm{ml}$ suspensions of $X$. campestris pv. vitians. In several cases, notably endive and cilantro, water-soaked leaf spots were observed similar to those seen on lettuce plants serving as positive controls. However, there is a notable lack of observations of a BLSlike disease on endive and other crops in the EAA. Evidence of differences in titration end points leads us to conclude that lettuce is clearly different in its hostparasite relationship to X. campestris pv. vitians than are the other crop species tested. Endive and similar plants may possess a low level of resistance to BLS that is controlled by a number of genes $(12,13,20)$. At inoculum concentrations of $10^{7} \mathrm{CFU} / \mathrm{ml}$ or greater, this generalized resistance is overcome under greenhouse conditions (29). Absence of symptoms in endive and other non-lettuce crops in the field may not be surprising given the inoculum threshold necessary to incite disease.

The electrolyte leakage studies with pepper and tomato confirm the results 
from the infectivity titration studies pointing to pepper as a probable host for $X$. campestris pv. vitians and tomato as an unlikely host. With pepper, a gradual increase in conductance and the peak conductance patterns were similar both for the strain of $X$. campestris pv. vitians and the compatible strain of the pepper race of $X$. axonopodis pv. vesicatoria. In contrast, the strain of the tomato race of $X$. axonopodis pv. vesicatoria induced a more rapid electrolytic leakage. Using these observations and the guidelines of Cook and Stall (7), pepper would appear to be a host of $X$. campestris pv. vitians, but tomato would, at best, be only a weak host. Sahin and Miller (28) reported both pepper and tomato as hosts of $X$. campestris pv. vitians. The differences in susceptibility of tomato in Ohio and Florida may be due to differ-
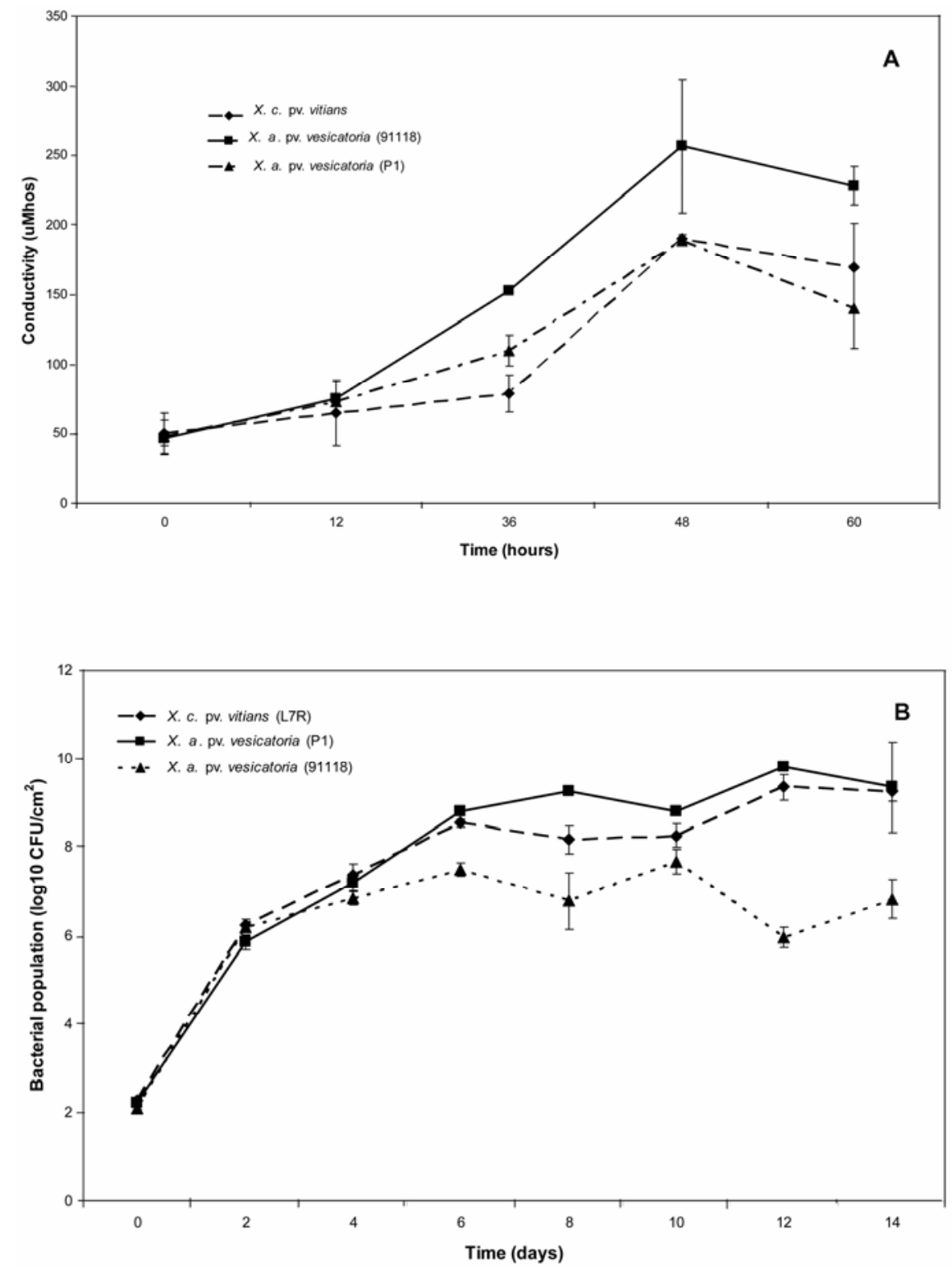

Fig. 4. Effect of infiltrating Xanthomonas campestris pv. vitians strain (L7R), a strain of the pepper race of $X$. axonopodis pv. vesicatoria (P1) which infects only pepper, and tomato race of X. axonopodis pv. vesicatoria strain 91118 , a T3 strain that infects tomato only, at $10^{8} \mathrm{CFU} / \mathrm{ml}$ on $\mathbf{A}$, electrolyte leakage $\mathbf{B}$, and bacterial populations in pepper plants. Means and standard error bars are shown for three replicates of each host/bacterium combination at each sampling time. crops are grown in close proximity, the risk might be much greater.

\section{ACKNOWLEDGMENTS}

We thank R. N. Raid and R. Nagata for providing vegetable seed and J. Minsavage and N. Havranek for technical assistance.

\section{LITERATURE CITED}

1. Agriculture and Agri-food Canada. 2003. Weather Data from Quebec Canada: http: res2.agr.ca/stjean/information. Agriculture and Agri-food Canada Horticulture Research and Development Center, Saint-Jean-Sur-Richelieu.

2. Anonymous. 1993. www.worldclimate.com.

3. Barak, J. D., Koike, S. T., and Gilbertson, R. L. 2001. The role of crop debris and weeds in the epidemiology of bacterial leaf spot of lettuce in California. Plant Dis. 85:169-178.

4. Brown, N. A. 1918. Some bacterial diseases of lettuce. J. Agric. Res. 13:367-388.

5. Carisse, O., Ouimet, A., Toussaint, V., and Philion, V. 2000. Evaluation of the effect of seed treatments, bactericides and cultivars on bacterial leaf spot of lettuce caused by Xanthomonas campestris pv. vitians. Plant Dis. 84:295-299.

6. Chamberlain, D. W. 1962. Reaction of resistant and susceptible soybeans to Xanthomonas phaseoli var. sojensis. Plant Dis. Rep. 46: 707709.

7. Cook, A. A., and Stall, R. E. 1968. Effect of Xanthomonas vesicatoria on loss of electrolytes from leaves of Capsicum annuum. Phytopathology 58:617-619.

8. Daboin, C., and Tortolero, O. 1991. Mancha bacterial foliar de la lechuga en algunos campos Andinos de Venezuela. Fitopatol. Venez. 6:8-10.

9. Edwards, B. H., Larson, R, and Hostetler, R. 1993. Calculus with Analytic Geometry. Houghton Mifflin Co., Boston.

10. Everglades Research and Education Center 2003. EREC Weather data from 1992-1993: http://erec.ifas.ufl.edu.

11. Ercolani, G. L. 1984. Infectivity titration of bacterial plant pathogens. Annu. Rev. Phytopathol. 22:35-52.

12. Flor, H. H. 1942. Inheritance of pathogenicity in Melamspora lini. Phytopathology 32:653669.

13. Flor, H. H. 1971. Current status of the genefor-gene concept. Annu. Rev. Phytopathol. 9:275-296.

14. Foster, R. L., and Echandi, E. 1973. Relation of age of plants, temperatures, and inoculum concentration to bacterial canker development in resistant and susceptible Lycopersicon sp. Phytopathology 63:773-777.

15. Hibberd, A. M., Stall, R. E., and Bassett, J. 1987. Different phenotypes are associated with incompatible races and resistance genes in the bacterial spot disease of pepper. Plant Dis. 70:337-339.

16. Jones, J. B., and Pernezny, K. 2003. Bacterial spot. Pages 6-7 in: Compendium of Pepper Diseases. K. Pernezny, P. D. Roberts, J. F. Murphy, and N. P. Goldberg, eds. American Phytopathological Society Press, St. Paul, MN.

17. Leben, C., Daft, G. C., and Schmitthenner, A. F. 1968. Bacterial blight of soybeans: Population levels of Pseudomonas glycinea in relation to symptom development. Phytopathology. 58:1143-1146.

18. Osterhout, W. J. V. 1912. The permeability of protoplasm to ions and the theory of antagonism. Science 35:112-115.

19. Osterhout, W. J. V. 1921. Conductivity and permeability. J. Gen. Physiol. 4:1-9.

20. Parveliet, J. E., and Zadoks, J. C. 1977. The integrated concept of disease resistance: a new view including horizontal and vertical resistance in plants. Euphytica 26:5-21. 
21. Patterson, C. L., Grogan, R. G., and Campbell, R. N. 1986. Economically important diseases of lettuce. Plant Dis. 70:982-987.

22. Pennisi, A. M., and Pane, A. 1990. Gravi epidemie di Xanthomonas campestris pv. vitians (brown) Dye su lattuga in Sicilia. Inf. Fitopatol. 40:56-58.

23. Pernezny, K, Raid, R. N., Stall, R. E., Hodge, N. C., and Collins, J. 1995. An outbreak of bacterial spot of lettuce in Florida caused by Xanthomonas campestris pv. vitians. Plant Dis. 79:359-360.

24. Sahin, F. 2000. First report of bacterial spot of lettuce caused by Xanthomonas campestris pv. vitians in Turkey. Plant Dis. 84:490.

25. Sahin, F., Abbasi, P. A., Lewis Ivey, M. L., Zhang, J., and Miller, S. A. 2003. Diversity among strains of $X$. campestris pv. vitians from lettuce. Phytopathology 93:64-70.

26. Sahin, F., Abbasi, P. A., and Miller, S. A. 1997. Variation among strains of Xanthomonas campestris pv. vitians isolated from lettuce in Ohio. (Abstr.) Phytopathology 87:S84.

27. Sahin, F., and Miller, S. A. 1997. Identification of the bacterial leaf spot of lettuce, Xanthomonas campestris pv. vitians in Ohio, and assessment of cultivar resistance and seed treatments. Plant Dis. 81:1443-1446.

28. Sahin, F., and Miller, S. A. 1998. Two new hosts of Xanthomonas campestris pv. vitians. Plant Dis. 82:262.

29. Staskawicz, B. J., Ausubel, F. M., Baker, B. J., Ellis, J. G., and Jones, J. D. G. 1995. Molecular genetics of plant disease resistance.
Science 268:661-667.

30. Toussaint, V. 1999. Bacterial leaf spot, a new disease of lettuce in Quebec caused by Xanthomonas campestris pv. vitians. Phytoprotection 80:121-125.

31. Tsuchiya, Y, Ohata, K., Azegami, K., and Matsuzaki, M. 1981. Pathogenicity of Xanthomonas campestris pv. vitians to various crops and weeds. Nogyo gijutsu kenkyusho hokoku. Bull. Nat. Inst. Agric. Sci. 35:57-66 (in Japanese).

32. Vose, R, Peterson, T., and Schmoyer, R. 2003. Quebec Average Temperatures. Buttle and Tuttle Ltd., Isle of Man, UK.

33. Wallis, F. M., and Joubert, J. J. 1972. Bacterial leafspot of lettuce in Natal. Phytolactica 4:137138. 